\title{
PENGARUH PENAMBAHAN BENTONIT PADA SEKAM PADI TERHADAP KINERJA TUNGKU GASIFIKASI TIPE DOWNDRAFT
}

\author{
Subroto \\ Fakultas Teknik, Program Studi Teknik Mesin \\ Universitas Muhammadiyah Surakarta \\ Email: sub224@ums.ac.id \\ Afif Faishal \\ Fakultas Teknik, Program Studi Teknik Mesin \\ Universitas Muhammadiyah Surakarta \\ Email: af515@ums.ac.id
}

\begin{abstract}
ABSTRAK
Sekam padi merupakan sampah organik yang sangat mudah di dapatkan di negara agraris seperti Indonesia. Sekam padi dapat dimanfaatkan menjadi sumber energi alternatif melalui proses gasifikasi untuk menghasilkan gas yang mampu bakar. Penelitian ini bertujuan untuk mengetahui pengaruh penambahan katalis bentonit pada sekam padi terhadap kinerja tungku gasifikasi tipe Downdraft. Proses gasifikasi pada penelitian ini dilakukan dengan cara menambahkan katalis bentonit pada bahan bakar sekam padi sebesar 100 gr, 150 gr, 200 gr. Setelah dilakukan penyalaan, diperoleh data berupa temperatur pembakaran, waktu penyalaan, waktu nyala efektif. Hasil pembakaran dimanfaatkan untuk mendidihkan air, yang mana digunakan untuk mencari besarnya kalor yang dihasilkan. Hasil penelitian ini menunjukkan bahwa temperatur rata-rata pembakaran tertinggi terjadi pada pengujian tanpa penambahan bentonit, yaitu $375,8^{\circ} \mathrm{C}$. Waktu penyalaan tercepat juga dihasilkan pada pengujian tanpa penambahan bentonit, yaitu selama 8 menit, sedangkan Waktu nyala efektif terlama dihasilkan pada pengujian dengan penambahan bentonit 150 gr, yaitu selama 44 menit. Kalor terbesar dihasilkan pada pengujian dengan penambahan bentonit 150 gr, yaitu sebesar $1719,519 \mathrm{~kJ}$.
\end{abstract}

Kata kunci: sekam padi, bentonit, gasifikasi, downdraft, katalis, temperatur pembakaran, waktu penyalaan, waktu nyala efektif, kalor.

\begin{abstract}
Rice husk is organic waste which is very easy to get in an agrarian country like Indonesia. Rice husk can be used as an alternative energy sources through the gasification process to produce gas that can burn. The purpose of this research is to determine the effect of addition of bentonite on rise husk to the downdraft gasification reactor performance. The gasification process in this research was carried out by adding bentonite catalyst to the rice husk fuel in $100 \mathrm{gr}, 150$ $\mathrm{gr}, 200 \mathrm{gr}$. After ignition, it can obtain the form of combustion temperature, ignition time, effective flame time. The results of combustion are used to boil water, which is used to find the amount of heat produced. The results of this research indicate that the highest average combustion temperature occurs in the test without the addition of bentonite, which is $375.8^{\circ} \mathrm{C}$. The fastest ignition time is also produced in the test without the addition of bentonite, which is for 8 minutes. In a while, the longest effective flame time is produced in the test with the addition of $150 \mathrm{gr}$ bentonite, which is for 44 minutes. The greatest heating value was generated in the test with the addition of $150 \mathrm{gr}$ bentonite, which amounted to $1719,519 \mathrm{~kJ}$.
\end{abstract}

Keywords: rise husk, bentonite, gasification, downdraft, catalyst, combustion temperature, ignition time, effective flame time, heating value. 


\section{PENDAHULUAN}

Salah satu sumber energi alternatif yang dapat dikembangkan adalah bahan organik yang ada di lingkungan sekitar, contohnya yaitu sampah organik sekam padi. Bahan organik merupakan bahan yang dapat diperbarui sehingga dapat digunakan untuk jangka panjang. Sekam padi dapat dimanfaatkan menjadi sumber energi alternatif melalui proses gasifikasi untuk menghasilkan gas yang mampu bakar. Pemanfaatan sampah organik berupa sekam padi sebagai sumber energi biomassa yang berkembang di masyarakat masih belum optimal. Melihat kondisi saat ini, perlu dilakukan pengembangan lebih lanjut tentang teknologi gasifikasi berbahan bakar sekam padi. Oleh karena itu, perlu dilakukan penelitian mengenai teknologi gasifikasi berbahan bakar sekam padi. Penelitian ini menggunakan tungku gasifikasi tipe Downdraft berbahan bakar sekam padi dengan kapasitas $2 \mathrm{~kg}$ dengan penambahan katalis bentonit pada variasi $100 \mathrm{gr}$, 150 gr, 200 gr. Pada peneilitian ini, diperoleh data berupa temperatur pembakaran dan temperatur pendidihan air terhadap waktu selama 60 menit. Berdasarkan data tersebut, dapat diketahui temperatur ratarata pembakaran, waktu penyalaan, waktu nyala efektif, serta kalor yang dihasilkan.

\section{TINJAUAN PUSTAKA}

[1] dalam penelitiannya mengenai gasifikasi pada biomassa padat biji kurma, menyimpulkan bahwa kalor maksimum yang dihasilkan sebesar $17.700 \mathrm{~kJ} / \mathrm{kg}$ pada kecepatan udara 2,2 m/s. Biomassa padat biji kurma sangat potensial untuk dijadikan sumber energi terbarukan apaila dimanfaatkan dengan benar. [2] melakukan penelitian pada tungku gasifikasi tipe downdraft kontinu dengan bahan bakar sekam padi, dan menyimpulkan bahwa kecepatan udara berpengaruh terhadap temperatur pembakaran, waktu penyalaan awal dan lama waktu nyala efektif yang dihasilkan. [3] dalam penelitiannya tentang peningkatan proses pirolisis bahan bakar dengan menggunakan bentonit, menyimpulkan bahwa penambahan bentonit ke beberapa biomassa dapat meningkatkan produksi hidrogen dan gas metana pada saat pirolisis berlangsung, meskipun terjadi pada temperatur yang rendah. [4] melakukan penelitian pada tungku gasifikasi Updraft berbahan bakar tandan kosong kelapa sawit dengan penggunaan bentonit sebagai katalis. Hasilnya diperoleh kesimpulan bahwa penambahan katalis Bentonit meningkatkan laju pemanasan serta laju produksi syngas. [5] melakukan penelitian tentang pengaruh penambahan katalis bentonit terhadap hasil gasifikasi Updraft tandan kosong kelapa sawit, dan menyimpulkan bahwa syngas dihasilkan paling banyak pada penambahan katalis bentonit 50\% dengan volume 60,563 liter dibandingkan dengan tanpa katalis yang hanya 51,055 liter.

\section{LANDASAN TEORI}

\subsection{Gasifikasi}

Gasifikasi adalah suatu proses perubahan bahan bakar padat menjadi gas, dimana udara yang diperlukan lebih rendah dari udara yang digunakan untuk proses pembakaran. Produk yang dihasilkan dapat dikategorikan menjadi tiga bagian utama, yaitu: padatan, cairan dan gas permanen.

\subsection{Jenis-jenis Thermal Process Gasification}

Berdasarkan arah aliran : Gasifikasi aliran searah (Downdraft gasification), Gasifikasi aliran berlawanan (Updraft gasification), Gasifikasi (Crosdraft).

\subsection{Tahapan Proses Gasifikasi}

\subsubsection{Drying atau Pengeringan}

Pada tahap pengeringan, kandungan air pada bahan bakar padat diuapkan oleh panas yang diserap dari proses oksidasi. 


\subsubsection{Pirolisis atau Devolatilisasi}

Pirolisis atau devolatilisasi disebut juga sebagai gasifikasi parsial. Proses Pirolisis dimulai pada temperatur sekitar $230^{\circ} \mathrm{C}$. Produk Pirolisis umumnya terdiri dari tiga jenis, yaitu gas ringan $\left(\mathrm{H}_{2}, \mathrm{CO}, \mathrm{CO}_{2}\right.$, $\mathrm{H}_{2} \mathrm{O}$ dan $\mathrm{CH}_{4}$ ), tar dan arang.

\subsubsection{Reduksi}

Char yang dihasilkan melalui reaksi pirolisis tidak sepenuhnya karbon tetapi mengandung hidrokarbon yang terdiri dari hidrogen dan oksigen. Maka, agar dihasilkan gas mampu bakar seperti hidrogen dan karbonmonoksida, char tersebut harus direaksikan dengan karbon dioksida. Produk yang dihasilkan pada proses ini adalah gas bakar, seperti: $\mathrm{H}_{2}, \mathrm{CO}, \mathrm{CH}_{4}$.

\subsubsection{Oksidasi atau Pembakaran}

Oksidasi atau pembakaran arang merupakan reaksi terpenting yang terjadi didalam gasifier. Hasil reaksi tersebut adalah $\mathrm{CO}_{2}$ dan $\mathrm{H}_{2} \mathrm{O}$ yang secara berurutan direduksi ketika kontak dengan arang yang diproduksi pada pirolisis.

\subsection{Sekam Padi}

Sekam padi merupakan limbah hasil penggilingan padi yang dikategorikan sebagai biomassa yang dapat digunakan untuk berbagai kebutuhan seperti bahan baku industri, pakan ternak dan energi atau bahan bakar.

\subsection{Katalis}

Katalis adalah suatu zat yang mempercepat laju reaksi kimia pada suhu tertentu, tanpa mengalami perubahan atau terpakai oleh reaksi itu sendiri. Suatu katalis berperan dalam reaksi tetapi bukan sebagai pereaksi ataupun produk. Penambahan katalis dapat membuat reaksi berlangsung pada temperatur lebih rendah sehingga energi aktivasi yang dibutuhkan menjadi lebih rendah dan energi yang dibutuhkan saat bereaksi menurun. Hal ini menghasilkan reaksi dapat berlangsung lebih cepat.

\subsection{Bentonit}

Bentonit merupakan sejenis tanah lempung yang secara alami mempunyai kemampuan mengembang sampai 15 kali volume keringnya jika menyerap air. Mineral bentonit memiliki diameter kurang dari $2 \mu \mathrm{m}$, yang mengandung silika, aluminiumoksida dan hidroksida yang dapat mengikat air [6].

\section{METODE PENELITIAN}

Penelitian ini dilakukan dengan metode eksperimental dengan melakukan pengujian gasifikasi pada tungu gasifikasi tipe Downdraft dengan kecepatan udara diatur konstan pada $6 \mathrm{~m} / \mathrm{s}$. Bahan bakar yang digunakan adalah biomassa sekam padi $2 \mathrm{~kg}$ dengan penambahan katalis bentonit sebesar 100 gr, $150 \mathrm{gr}$, dan 200 gr.

Data yang diperoleh yaitu temperatur pembakaran, waktu penyalaan, waktu nyala efektif, dan kalor. Waktu Penyalaan dihitung dari awal mula dilakukan penyalaan hingga temperatur pembakaran berada diatas $150^{\circ} \mathrm{C}$. Waktu nyala efektif dihitung ketika temperatur pembakaran berada diatas $150^{\circ} \mathrm{C}$ hingga kembali turun pada $150^{\circ} \mathrm{C}$ saat gas hasil gasifikasi sudah habis. Hasil pembakaran dimanfaatkan untuk mendidihkan air yang kemudian digunakan untuk menghitung besarnya kalor. 


\section{ALAT DAN BAHAN PENELITIAN}

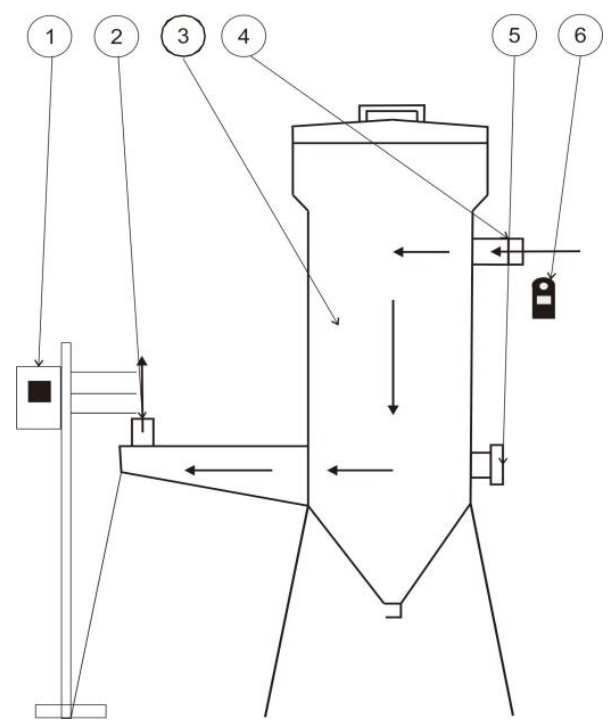

Gambar 1. Instalasi alat penelitian

Keterangan:

1. Thermocouple Thermometer

2. Saluran Keluar Gas

3. Tungku Utama

4. Saluran Masuk Udara

5. Saluran Ignition

6. Anemometer

\section{HASIL DAN PEMBAHASAN}

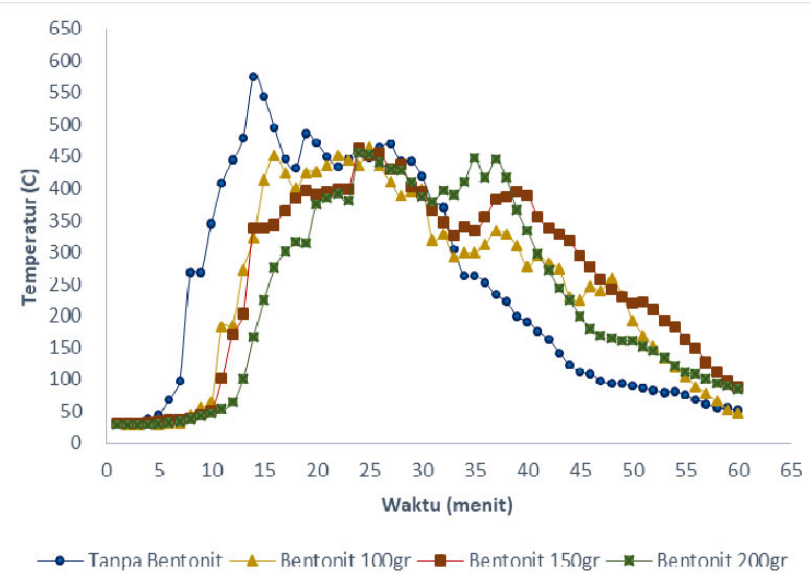

Gambar 2. Perbandingan temperatur pembakaran tungku gasifikasi tipe downdraft berbahan bakar sekam padi dengan penambahan bentonit. 
Berdasarkan Gambar 2, diketahui pengujian tungku gasifikasi tanpa penambahan katalis bentonitmenghasilkan temperatur nyala api rata-rata sebesar $375,8^{\circ} \mathrm{C}$.Pada penambahan katalis bentonit 100 gr, temperatur nyala api rata-rata yaitu $325,0^{\circ} \mathrm{C}$. Pengujian dengan penambahan bentonit 150 gr menghasilkan temperatur nyala api rata-rata sebesar $331,6^{\circ} \mathrm{C}$. Pada pengujian penambahan katalis bentonit 200 gr didapatkan temperatur nyala api rata-rata sebesar $325,2^{\circ} \mathrm{C}$.

Waktu penyalaan pada pengujian tungku gasifikasi tanpa penambahan katalis Bentonit lebih cepat dibandingkan pengujian dengan penambahan katalis Bentonit. Hal ini disebabkan oleh sifat Sodium Bentonit yang tidak mudah terbakar atau non-flammable dan non-reactive.

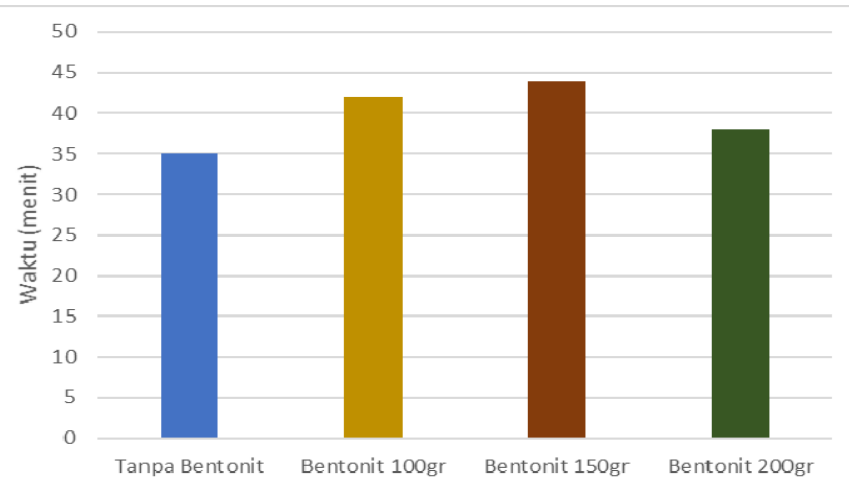

Gambar 3. Perbandingan waktu nyala efektif tungku gasifikasi tipe downdraft berbahan bakar sekam padi dengan penambahan bentonit

Penambahan Bentonit dapat meningkatkan produksi gas metana pada tahap pirolisis dalam proses gasifikasi sekam padi meskipun terjadi pada temperatur yang rendah [3]. Maka dari itu, jumlah produksi gas yang dihasilkan pada gasifikasi sekam padi dengan penambahan katalis Bentonit lebih banyak dibandingkan dengan tanpa penambahan Bentonit. Produksi gas terbanyak dan paling optimal terjadi pada pengujian dengan penambahan katalis Bentonit 150 gr.

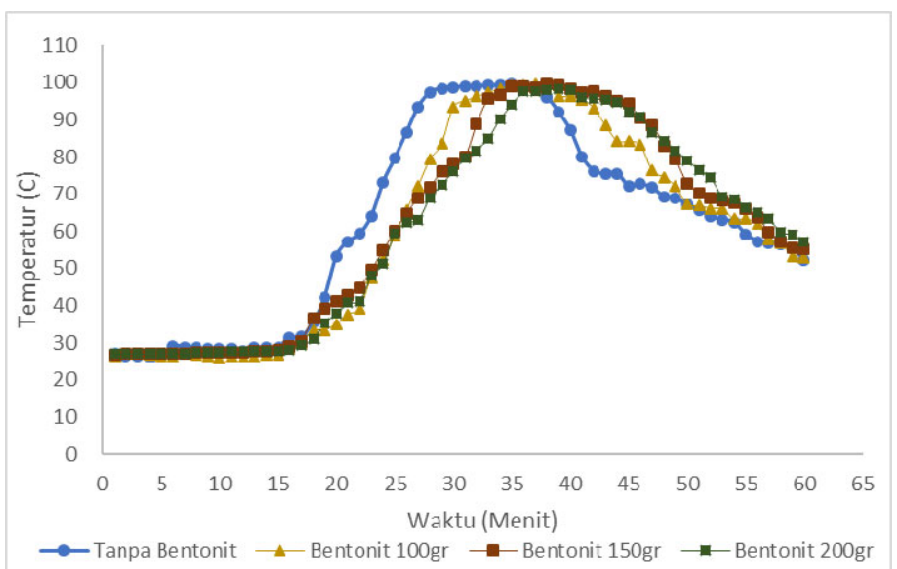

\section{Gambar 4. Perbandingan waktu pendidihan air tungku gasifikasi tipe downdraft berbahan bakar sekam padi dengan penambahan bentonit}

Berdasarkan Gambar 4, dapat diketahui bahwa pada pengujian tanpa penambahan Bentonit membutuhkan waktu 28 menit untuk mendidihkan 1500 gr air, pada penambahan Bentonit 100 gr dibutuhkan waktu 31 menit, disusul penambahan Bentonit 150 gr yang membutuhkan waktu 33 menit, dan 
pada penambahan Bentonit 200 gr dibutuhkan waktu 36 menit untuk mendidihkan 1500 gr air. Waktu pendidihan air dipengaruhi oleh nyala api yang dihasilkan dari tungku gasifikasi.

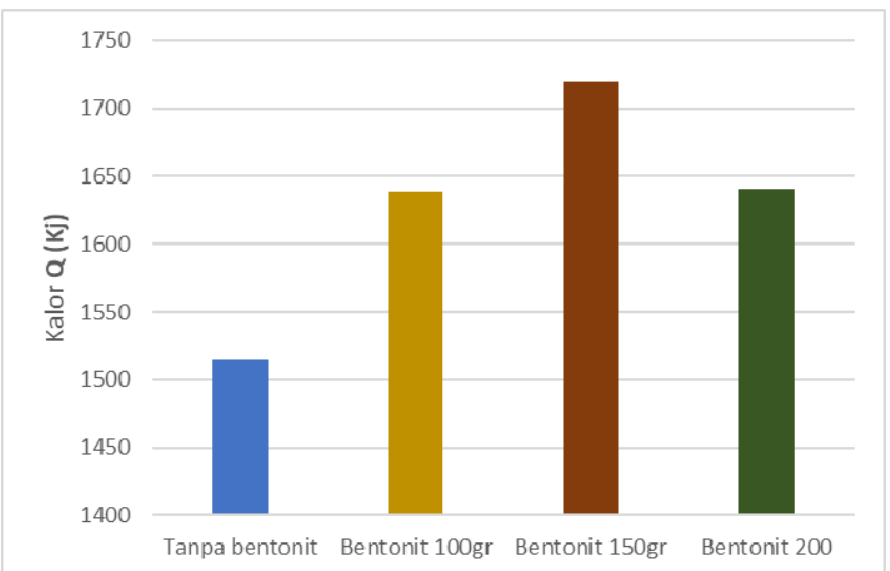

Gambar 5. Perbandingan kalor pendidihan air tungku gasifikasi tipe downdraft berbahan bakar
sekam padi dengan penambahan bentonit

Berdasarkan Gambar 5, dapat diketahui bahwa kalor pada pengujian tungku gasifikasi tanpa penambahan bentonitadalah sebesar 1529,294 kJ, pada penambahan bentonit 100 gr menghasilkan nilai kalor sebesar 1638,182 kJ, pada penambahan bentonit 150 gr dihasilkan nilai kalor sebesar 1719,519 Kj, serta pada penambahan bentonit 200 gr dihasilkan nilai kalor sebesar 1640,495 kJ. Kalor tertinggi didapatkan pada pengujian dengan penambahan bentonit $150 \mathrm{gr}$, sedangkan kalor terendah dihasilkan pada pengujian tungku gasifikasi tanpa penambahan bentonit.

\section{KESIMPULAN}

Berdasarkan analisa dan pembahasan dari hasil pengujian tungku gasifikasi tipe downdraft berbahan bakar sekam padi pada variasi penambahan katalis bentonit, dapat diambil kesimpulan sebagai berikut :

1. Temperatur pembakaran rata-rata tertinggi dihasilkan pada pengujian tanpa penambahan bentonit, sedangkan yang terendah dihasilkan pada pengujian penambahan bentonit 100 gr.

2. Waktu penyalaan tercepat dihasilkan pada pengujian gasifikasi tanpa penambahan bentonit, sedangkan waktu penyalaan terlama dihasilkan pada pengujian penambahan bentonit $200 \mathrm{gr}$.

3. Waktu nyala efektif terpanjang dihasilkan pada pengujian gasifikasi dengan penambahan bentonit 150 gr. Penambahan bentonit mampu meningkatkan produksi gas metana, sehingga mengakibatkan waktu nyala efektif menjadi lebih panjang.

4. Kalor tertinggi dihasilkan pada pengujian dengan penambahan bentonit 150 gr. Penambahan bentonitmampu meningkatkan kalor karena gas yang dihasilkan lebih banyak dan waktu nyala efektif yang lebih panjang.

\section{DAFTAR PUSTAKA}

[1] J. Al Asfar, “Gasification of Solid Waste Biomass,” Journal of Mechanical and Industrial Engineering, 2014.

[2] N. Saputra, Pengaruh Variasi Kecepatan Udara Terhadap Kinerja Tungku Gasifikasi sekam Padi Tipe Downdraft Kontinu. Universitas Muhammadiyah Surakarta, 2016. 
[3] G. Dou, "In situ upgrading of pyrolysis biofuels by bentonite clay with simultaneous production of heterogeneous adsorbents for water treatment," Journal Departement of Mechanical Engineering.

[4] A. Rofi'udin, "Pengaruh Penambahan Katalis Bentonit Terhadap Gasifikasi Updraft Tandan Kosong Kelapa Sawit Pada Temperatur $700^{\circ}$ C," 2018.

[5] A. Y. Sabitah, Gasifikasi Biomassa Limbah Sawit Dengan Penambahan Katalis Bentonit. Universitas Brawijaya, 2018.

[6] Alvin, Karakteristik Bentonit Teknis Sebagai Adsorben Indigo Biru. Yogyakarta: Universitas Gadjah Mada, 2012.

[7] D. Turdjaja, Eksplorasi Umum Endapan Bentonit Di Kabupaten Manggarai Barat, Nusa Tenggara Timur. Kelompok Penelitian Mineral, 2007.

[8] M. R. Khoiri, Rancang Bangun Tungku Gasifikasi Tipe Downdraft Continue Bahan Bakar Sekam Padi. Universitas Muhammadiyah Surakarta, 2016. 